\title{
Adapting Yorùbá Epistemology in Educational Theory and Practice in Nigeria
}

\author{
Oluwatoyin Vincent Adepoju \\ Comparative Cognitive Processes and Systems (Compcros) \\ http://danteadinkra.wixsite.com/compcros \\ toyin.adepoju@gmail.com
}

\begin{abstract}
What is the value of Yoruba epistemology, theory of knowledge, particularly its philosophy of perception, to humanity in general, and to contemporary Nigeria, in particular? How does Yorùbá epistemology connect with educational theory and practice in Nigeria? This essay recognizes but goes beyond the more general overviews on classical Yoruba education and its contemporary significance represented in works of Yorùbá and Africanist scholars. I demonstrate the significance of Yoruba philosophy of education beyond its cultural context, by projecting its universal and timeless value, foregrounding its distinctive concepts in dialogue with ideas from other cultures. In its engagement with Nigerian educational dynamics, the essay concentrates, first, on Yoruba epistemology in its intersection with ethical and metaphysical perspectives from Yoruba thought. Second, the essay deploys the African art-centered investigations of the role of the senses in relating with art, understood as paradigmatic of navigating the world.
\end{abstract}

Keywords: Yorùbá epistemology, Sense perception, Education, oju inú I oju òde, Creativity 


\section{Cultivating Creativity and Transcending Dissolution}

What is the value of Yorùbá epistemology, theory of knowledge, particularly its philosophy of perception, to humanity in general, and to contemporary Nigeria, in particular? This philosophy may inspire appreciation of the scope of human potential, of strategies for developing depth of insight into phenomena and of cultivating creativity, in the context of the aspiration to transcend mortality and participate in the eternal, even if that transcendence is not experienced in physical terms. This range of possibility is depicted by this philosophy in terms of a relationship between epistemology, ethics and metaphysics, a perception of the essential nature of an entity, an inward identity that in humans may be seen as including quality of personality.

In a country torn between the possibility of self-transcendence in the name of the greater good and self-focus at the expense of the larger whole, Yorùbá philosophy's emphasis on values that rise above the pervasive and unavoidable degenerative character of mortality could inspire an appreciation of the need to live for principles that surpass immediate and self-centred gratification.

\section{Contextualization}

\section{In Relation to Yorùbá Philosophy of Education}

This essay recognises but goes beyond the more general overviews on classical Yorùbá education and its contemporary significance represented in works by Fayemi (2009), Akinwale (2013), Adebisi (2015), and other more specific assessments represented by Tony Idowu Aladejana's discussion of ethics in the context of a broader structure of Yorùbá education (1979), as well as the various other issues raised by Akinsola (2011), and Hyland (2016), the latter remarkable in its bold dialogue between Yorùbá thought and a school of Indian philosophy, an effort to which this essay bears some thematic and methodological relationship in emphasizing the agency of the learner as inspired by Yorùbá thought, reinforced by other African and Asian and Western philosophies. This essay differs from Hyland's work, however, in emphasising a degree of depth of analysis of conceptions in Yorùbá philosophy in place of the broader comparative exploration of Yorùbá and Vedantic thought undertaken by Hyland.

Like Yusef Waghid in African Philosophy of Education Reconsidered (2014), I demonstrate the significance of Yorùbá philosophy of education beyond its cultural context, projecting its universal and timeless value, foregrounding its distinctive concepts in dialogue with ideas from other cultures, though while Waghid centres his analysis in the East African concept of Ubuntu, I 
concentrate on Yorùbá epistemology in its intersection with ethical and metaphysical perspectives from Yorùbá thought.

\section{In Relation to Theories of Perception, Yorùbá and Non-Yorùbá}

This essay is an elaboration upon the close investigation of Yorùbá philosophy in which the work of Lawal (2001), ${ }^{1}$ Abiodun $(2014),{ }^{2}$ Hallen $(2000)^{3}$ and Olubi Sodipo (1994) ${ }^{4}$ is foundational, recognising the controversies about styles of engaging Yorùbá philosophy evident in their works. The essay proceeds, however, in the understanding of the necessarily interpretive character of philosophical thought, whether in an exposition of the history of ideas or an expansion of possibilities drawn from extant conceptions or in the building of relatively new ideas.

The focus here is on engagement with Yorùbá philosophy as less of a report about philosophy as has been done in classical Yorùbá culture but more as a demonstration of how ideas from Yorùbá thought may be employed as inspirational sources, as matrices for contemporary philosophical reflection. The emphasis here is on the act of doing philosophy, rather than reporting on how classical Yorùbá philosophy worked or works. The historical context is foundational but acts as a platform for reflection on the creative possibilities of the ideas being engaged with. The essay also moves away from questions as to the degree to which the ideas in question are representative of Yorùbá thought as a whole ${ }^{5}$ to a focus on these ideas as sources of ideation which have arisen from a particular cultural context and which can provoke reflection as to their contemporary significance.

This essay also represents an effort to use decontextualized proverbs as loci of philosophical reflection. While it is true that proverbs are often most fully actualized in context, it may be argued that they embody a core of meaning, an interpretive centre, that enables their employability within a broad situational network. The method of interpreting proverbs demonstrated here

1 My particular interest is in the passage focusing on epistemology in Lawal (2001).

2 Abiodun (2014) may be seen as summative of the thrust of Abiodun's work so far.

3 This text is of central relevance to this essay.

4 Hallen and Olubi Sodipo (1994) is a rich discussion of the Yorùbá conception of inwardness in relation to consciousness.

5 This statement is inspired by Suzanne Preston Blier's rejoinder, "A Partial Response to Rowland Abiodun's Critique", academia.edu. https://www.academia.edu/12113166/A partial response to Rowland Abioduns critique (accessed 27/02/18) to Rowland Abiodun's criticism in Yoruba Art and Language: Seeking the African in African Art, of her stance on how to use classical Yorùbá thought in investigating Yorùbá art in its historical development. 
aspires to explore that semantic core. ${ }^{6}$ The essay belongs in the continuum of African art centred investigations of the role of the senses in relating with art, understood as paradigmatic of navigating the world, represented by the semioptics of Moyo Okediji, "an approach that recognises the limitations of the linguistic thrust of semiotics [the study of signs] and seeks to uncover the ways in which the sense of sight shapes our perceptions and understandings of the world"; and Henry John Drewal's sensiotics, "an inclusive and comprehensive project of developing...theories and methods to reveal the bodily, multi-sensorial basis of understanding of arts." Drewel declares that "...before language, we began [begin?] by perceiving, reasoning, theorizing, and understanding through all our senses.... Seeing (hearing, tasting, etc.) is thinking. Sensing is theorizing. In the beginning, there was no word, only sensations." 8 To the grounding in African art and thought in dialogue with

6 The sixth chapter of Hallen (2000), titled "Rationality, Individuality, Secularity and the Proverb", discusses the challenges involved in interpreting proverbs, referencing a rich body of scholarship on the subject, stating "In my opinion the most philosophically sophisticated exponent of proverbs as components of a culture's philosophical thought is Kwame Gyekye (1987/1995). Himself an analytic philosopher, Gyekye explicitly acknowledges these same problems for the exegesis of proverbs and then proposes to come to terms with them by acknowledging that proverbs can be used only as "a source of knowledge of African traditional philosophy" (p. 24) rather than the only or major source, and that their "topical" nature can be utilized in a positive manner if they are treated as distillations of a culture's knowledge about specific themes (pp. 16-19). I also find inspiring his quote from Gyekye, "Nor has there been any real attempt to weave appropriate proverbs together in order to construct a coherent ethics or moral philosophy of the Akans" (Gyekye 1987/1995, p. 16)."

7 Moyo Okediji's CV at https://art.utexas.edu/sites/files/aah/cv-moyo-okediji-1.pdf (accessed 28/02/18) demonstrates that he began developing this concept from his $\mathrm{PhD}$ dissertation "Semioptics of Anamnesia: Yoruba Images in the Works of Jeff Donaldson, Howardena Pindell and Muneer Bahauddeen." Ph.D. (African and African American Art), University of Wisconsin, Madison, 1995, continuing with "Museums, Modernity and Mythology: A Semioptic Review," RES 52, Fall 2007, "Semioptics of Africana Arts," in The African Diaspora and the Disciplines, Tejumola Olaniyan and James Sweet, eds, (Bloomington: Indiana University Press), 2010, pp 382-416, "Semioptics of Falolaism: Visual fractures Beyond Ethnic Boundaries," in Toyin Falola: The Man. The Mask, The Muse, Niyi Afolabi, ed. (Durham: Carolina Academic Press), 2010, pp.263-280, and beyond the CV, "African Art and Language as Semioptic Text", The Art Bulletin, 97:2, 2015. 123-139.

8 These quotations are from Henry John Drewal's "Making Sense of Yoruba-ness and Yoruba Arts", a rich draft published on the document archive Scribd at https://www. scribd.com/document/206826267/drewal ( accessed 28/02/18), which seems to be a longer version of his "African Art and the Senses", http://www.sensorystudies.org/sensorial-investigations/african-art-and-the-senses/(accessed 28/02/18), published in the online journal Sensory Studies, http://www.sensorystudies.org/, centred in the study of the senses across disciplines. The journal also references another journal focused on the same goal, The Senses and Society, its statement of purpose summing up the field admirably: "A 
Western thought that Okediji and Drewal bring to this subject, I add an engagement with Asian art and thought, expanding and further concretizing the scope of these investigations.

The essay is grounded in the same platform of engagement with the senses as primary means of knowing in the Western tradition represented by such scholarly and artistic/philosophical contexts as the understanding of the senses enabling a grasp of the source of existence, in the transcendental Platonic sense, ${ }^{9}$ the embodied Aristotelian sense, ${ }^{10}$ the understandings of sense perception running through Romantic and Symbolist thought to such relatively recent developments as work on the embodied mind, ${ }^{11}$ Hans Jonas on perception, ${ }^{12}$ Martin Heidegger on visualisity in Greek thought, and Antonio Cimino and Pavlos Kontos edited Phenomenology and the Metaphysics of Sight (2015). ${ }^{13}$ This essay differs from this cognitive stream in the essay's focus on

heightened interest in the role of the senses in culture and society is sweeping the human sciences, supplanting older paradigms and challenging conventional theories of representation. This pioneering journal provides a crucial forum for the exploration of this vital new area of inquiry. ...Sensation is fundamental to our experience of the world. Shaped by culture, gender and class, the senses mediate between mind and body, idea and object, self and environment." http://www.sensorystudies.org/the-senses-and-society/, (Accessed 28/02/18). Drewal (2016) elaborates on sensiotics in relation to the Yorùbá origin Ifa system of knowledge and divination". Other publications by Drewal along similar lines include (2005a, 2005b, and 2009), a number of videos on his university page at the University of Wisconsin-Madison (http://www.henrydrewal.com/) and, according to his CV at http://www.henrydrewal.com/bio-cv.html and https://arthistory.wisc.edu/people/ faculty/drewal (all three links accessed 28/02/18), the forthcoming "Sensiotics: Senses in Understandings of Material Culture, History, and the Arts," Oxford Handbook of History and Material Culture. Oxford University Press.

9 Plato's understanding of a quality in a trans-material realm acting as templates for the material world is described as presented at its best in the Republic.

10 Aristotle opens his exploration of the foundational structures of existence, of the nature of being as a quality that defines all existents, the Metaphysics, with a reference to the cognitive powers of sight. A presentation of points of entry into Aristotle is provided in note 38 .

11 The Wikipedia article "Embodied Cognition", https://en.wikipedia.org./wiki/Embodied cognition, (accessed 28/02/18) is a very useful survey of the subject. Central texts include Francisco Varela et al (1991) and Lakoff and Johnson (1999).

12 I use Jonas (1954 and 1962) in representing various developments in explorations of the senses in Western thought that do not belong to particular movements of ideas.

13 I am referencing Backman $(2015,11)$ which presents a rich comparison with the Yorùbá and Igbo Afa optical conceptions central to this essay: "Among modern interpreters, it has become a commonplace to regard the classical Greeks as a "people of the eye" with a general predilection for the visual sense. One of the most prominent facets of this alleged Greek visuality is the predominance of optical terms and metaphors in the Greek language and particularly in its philosophical terminology, extending to its most funda-

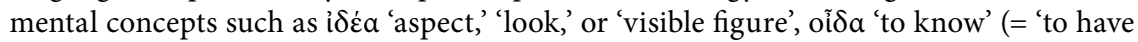


a network of ideas in a non-Western philosophical canon, opening out, however, to a degree on engagement with the lineage of ideas developed in the history of Western thought.

The essay is also related to idea about sensory perception in Asian thought, with particular reference to the body of ideas and practices known as Tantra, ${ }^{14}$ focusing on Tantra's building on ideas already powerfully developed in the seminal religious and philosophical Indian and Hindu text, the Upanishads, ${ }^{15}$ and later cultivated with particular force in such Tantric contexts as the image of the weapons of the Goddess Tripurasundari, symbolizing each of the senses as both alluring and constricting, inspiring a focus on the delightful surface of reality represented by the stimuli to sensory perception, and potentially expansive, in suggesting the possibility of moving beyond the

seen'), and $\theta \varepsilon \omega$ pia 'contemplation' (the disinterested look of the spectator). Undoubtedly the most influential interpretations of Greek thought as a metaphysics of vision and visibility, and of the implicit understanding of being underlying this imagery, are those of Martin Heidegger, who develops his readings into a critical account of the foundations of the Western metaphysical tradition as a whole". The title Phenomenology and the Metaphysics of Sight suggests the concern of this essay with interpreting Yorùbá philosophy of perception in terms of a movement from the immediate data of sense experience to interpretation of sense experience reaching to the most encompassing metaphysical insights and relating this focus in Yorùbá thought to other bodies of knowledge, within and beyond African systems of thought, that pursued similar goals.

14 What exactly Tantra is, is controversial in the scholarly literature. The Wikipedia article "Tantra" https://en.wikipedia.org/wiki/Tantra (accessed 28/02/18) is a rich introduction. Philip Rawson's Art of Tantra. London: Thames and Hudson, 2012 and David Gordon White's Tantra in Practice. Princeton: Princeton UP, 200, represent two perspectives. My focus in understanding this body of ideas and beliefs is centred in the use of embodiment as a means of both participating in the fulfilment provided by the senses as a dramatization of the joy of life and the employment of this fulfillment in embodiment as a means of penetrating to the source of being which enables this embodiment, a style of thought and action represented pre-eminently by the Vijñana Bhairava Tantra, the translation in Paul Reps' Zen Flesh, Zen Bones (1957) where I first encountered it, being both lucid and demonstrative of the quiet incandescence of the text. The adaptation of embodiment in seeking the trans-material is at times visualised in terms of the harmony of a transcendent principle, often associated with the God Shiva and an immanent principle, represented by the Goddess Shakti, united as flame and the heat of the flame, as Abhinavagupta puts it in his Tantraloka, a clear and yet eloquent translation known to me of the interpretive depths of its first chapter where this idea is introduced is that by Mark Dyczkowski accessible at his website http://www.anuttaratrikakula.org/. Accessed 28/02/18.

15 I allude here particularly to the magnificent lines from Book V of the Brihadaranyaka Upanishad which celebrates all aspects of the material world as expressions of the immortal essence of being, "This earth is the honey of all beings; all beings the honey of this earth. The bright eternal Self that is in earth, the bright eternal Self that lives in this body, are one and the same; that is immortality, that is Spirit, that is all... Self is the honey of all beings; all beings the honey of Self. The bright eternal Self that is everywhere, the bright eternal Self that lives in a man, are one and the same; that is immortality, that is Spirit, that is all..." (Yeats and Swami 1937, 133-135). 
immediately evident to the source of the attractions revealed by the senses in a zone of being beyond but embracing the material universe. ${ }^{16}$

\section{The Scope of Yorùbá Theory of Perception}

One of the most comprehensive summations of human cognitive capacity known to me consists in accounts of a Yorùbá theory of perception as described by Babatunde Lawal in "Àwòrán: Representing the Self and its Metaphysical Other in Yoruba Art" (2001) and by Rowland Abiodun in Yoruba Art and Language (2014), and its complementarity with Igbo Afa theory of perception as presented by John Umeh in After God is Dibia: Igbo Cosmology, Divination and Sacred Science in Nigeria (1999), and its conjunction with Zulu epistemology as elaborated by Mazisi Kunene in Anthem of the Decades (1981).

These conceptions range from the conventional, to the elevated, the fantastic and the cosmic. I have explored, at the level of theory, the convergences of these ideas with philosophies from different cultures in Asia, Europe and the Americas. I have practised different cognitive disciplines and gained various experiences, a number of them fantastic and puzzling. These African ideations have proven indispensable in helping me integrate these experiences in a cohesive manner. In asking myself the question of how they may be related to education understood as a formal method of developing knowledge, in the context of the relevance of Yorùbá philosophy to contemporary Nigerian issues, I am challenged to enquire as to the significance of these explorations for myself, for others and how others could take advantage of them. I will organise these reflections in terms of theory and practice, the two platforms of an educational system.

16 This visual depiction and its explanation is provided in the ritual the Sri Devi Khadgamala Stotram, the translation and presentation by the Shakti Sadhana Group Sri Devi Khadgamala Stotram: A Practice Text. (C) 2004 - 2006 by the Shakti Sadhana Group (accessed 28/02/18) being the most informative known to me. Between the sections known as the seventh and the eight enclosures in the ritual, is the section named 'Weapons of the Divine Mother' where the Goddess is saluted as "She who carries the five flower-arrows of Kama [pleasure as a fundamental creative principle of existence] - which are the senses of sound (music), touch (eros), form (beauty), taste (sweetness), and smell (fragrance)" and as "She who carries the sugarcane bow (i.e., the mind, which likes the sweet things of life), with its string of bumblebees". 25. I sum up this survey of philosophies of sense perception, particularly of sight, in relation to Yorùbá thought, in a diagrammatic form in "Theories and Practices of Cognition: Sense Perception and Metaphysical Integration in Western Asian Islamic and African Thought": https://www.academia.edu/13009066/ Theories and Practices of Cognition Sense Perception and Metaphysical Integration in Western Asian_Islamic and African_Thought Accessed 28/02/18. 


\section{Yorùbá Theory of Perception in Relation to Creativity}

A central challenge facing Nigeria is the question of how to maximize the country's potential for development. Central to development is creativity, and, in a capitalist economy like Nigeria's, entrepreneurial investment in creativity is central to actualizing its potential. Yorùbá theory of perception, as described by Lawal, suggests an outline of how creativity may be developed through the cultivation of the full range of human faculties, from the ratiocinative to the supra-rational. This theory may be interpreted to indicate an emphasis on the senses as the primary platform through which knowledge is gained. From this foundation, greater degrees of penetration into the possibilities of the phenomena in question may be reached through a perceptual continuum ranging from critical thought to imagination, intuition, extra-sensory perception and witchcraft, these categories of knowledge being valid possibilities I shall define, discuss and exemplify in the course of this essay.

Lawal's summation describes human cognitive progression in terms of a movement from ojú òde, the external eye, also known as ojú lásán, the ordinary or naked eye, to ojú inú, the inward eye, also depicted as ojú ọàn, the mind's eye. Ojú òde is basic vision centred in the perception of material realities. Ojú inú is inward discernment which penetrates deeper into the nature of phenomena through a perceptual continuum. This continuum may be seen as ranging from conventional perception represented by visual cognition, thinking, imagination, intuition, memory, and critical analysis to entry into non-conventional forms of knowing demonstrated by dreams, trances, prophecy, divination, extrasensory perception and witchcraft:

...the Yoruba call the eyeball eyin ojú, a refractive "egg" empowered by àșe (mediated by Eșu) [the òrișà or deity of transformation and paradox, intersecting various forms of being and different modes of knowledge], ${ }^{17}$ enabling an individual to see (ríran). As with other aspects of Yoruba culture, the eyeball is thought to have two aspects, an outer layer called ojú òde (literally, external eye) or ojú lásán (literally, naked eye) or ojú ọkàn (literally, mind's eye). ${ }^{18}$

The latter is associated with memory, intention, intuition, insight, thinking, imagination, critical analysis, visual cognition, dreams, trances, prophecy, hypnotism, empathy, telepathy, divination, healing, benevolence, malevolence, extrasensory perception, and witchcraft, among others. For the Yoruba, these

17 Idowu (1962) provides a rich introduction to Esșù. Fatunmbi (2000) develops a creatively expansive interpretation of Ėsù based om the traditional context. Gates Jr (1988) builds a comprehensive analysis of the significance of Ėșù. Falola's edited text (2013) is an encyclopaedic exploration of Èșù thought.

18 Lawal (2008) discusses duality in Yoruba culture. 
two layers combine to determine iwòran, the specular gaze of an individual (Lawal 2001, 516).

\section{From Sense Perception to Cosmic Vision}

This description of Yorùbá theory of perception is complemented by John Umeh's account of the epistemology of Afa, a classical Igbo spiritual and philosophical system, dramatizing the similarities between the geographically close Igbo and Yorùbá civilizations within what has become Nigeria. Umeh describes Afa theory of perception as based on the relationship between ose naabo, the eyes with which the material world is perceived and ose ora, the eye with which both the material world and the world of spirit are cognized in an integrative vision. The perceptual capacity of ose ora reaches a climax in insight into the unity of being within the ambit of eternity (Umeh 1999).

The Yorùbá expression, àikú parí iwà, which may be translated as "deathlessness consummates existence or being," is correlative with the Igbo Afa conception as depicted by Umeh. Complementing this expression is another observation from Yorùbá thought, iwà l' ẹwà, which may be interpreted as "character or inward being is beauty" (Abiodun 2014). Can an engagement with ewà, beauty, as the essence of an entity, particularly a human person, on account of the relationship between human agency and ethics enabling beauty or ugliness of personality, lead to a realization of "àikú", immortality or eternity? Can this idea, resonant with similar conceptions from various cultures, be understood as one interpretation of the relationship between these terse formulations from Yorùbá thought, iwà l'ẹà, "character or inward being is beauty" and àikú parí ìwà, "deathlessness consummates existence or being"?

One approach to entry into the possible conjunction between iwà l'ewà and àikú parí ìà is represented by a line in Western thought descending from the Greek philosopher Plato, which sees beauty as one of the underlying forms of existence, a fundamental form accessible to humanity. ${ }^{19}$ Within this context, àikú parí iwà, the consummation of being in deathlessness, may be seen as a penetration into the transcendence of mortality through a metaphysical immortality, a dimension of existence involving participation in the ground of being and thus going beyond the dissolutions of materiality. It may thus be appreciated as a form of mystical awareness, an example of theories and practices of experiential immersion in ultimate reality in terms of which mysticism may be understood. ${ }^{20}$

19 This idea is particularly well developed in Plato's Republic.

20 I provide a summation of comparative mystical theory and practice that, though very brief, is pioneering in integrating a discussion of mysticism in classical and post-classical African cultures, on Facebook at the following links "Mystical Theory and Experience Across Cultures Part 1" : https://www.facebook.com/ 
A related perspective is developed in the Indian Katha Upanishad, correlating death and immortality as the Yorùbá expression does, within the dramatic context of a conversation between Nachiketas and Death, in which Nachiketas requests to know how to transcend death. After much persistence suggesting the priceless character of the answer to the question, he is informed that the union of the individual self with the universal Self through the discipline of study, concentration and renunciation leads, though still on earth, to soaring above death and birth and mounting into ultimate reality. ${ }^{21}$ Another approach to the eternal, again contrasting eternity with mortality, as in the Yorùbá conception, is demonstrated by the German philosopher, Immanuel Kant, in which he describes his mind as reaching into infinity, in contradiction of his necessarily brief human mortality within the diminutiveness of the earth, these temporal and spatial circumscriptions highlighted by the background constituted by the spatial and temporal immensity of the celestial bodies. ${ }^{22}$ These ideational conjunctions exploring the implications of the Yorùbá expression àikú parí ìwà, within an intercultural framework, may be subsumed by the Nigerian Cross River Nsibidi symbolism of the spiral, which, like the Kantian evocation of eternity in the context of the temporal motion of a life span against the background of the revolutions of the celestial bodies, is described as suggesting the sun, journey and eternity. ${ }^{23}$

This effort at teasing out the intrinsic semantic value and associative possibilities of the Yorùbá conception àikú parí iwà, the consummation of being in

notes/oluwatoyin-vincent-adepoju/mystical-theory-and-experience-across-cultures-part-1/10152209719269103 and "Mystical Theory and Experience Across Cultures Part 2" : https://www.facebook.com/notes/oluwatoyin-vincent-adepoju/mystical-theory-and-experience-across-cultures-part-2/10152944419179103/. Accessed 18/02/2018. The scope of scholarship on mysticism is represented by the temporal distance and difference in orientation between and yet correlative relevance of two strategic works in the field, James (1902) which demonstrates similarities amongst experiences described a mystical, and Katz (2013) which tries to demonstrate the difference in unity between accounts of mystical theory and practice. Neither of these works refers to mysticism in the context of classical African spiritualities or as developed by Africans outside the context of religions imported into Africa.

21 My favourite version is Yeats and Swami (1937). The Katha Upanishad runs from pages 25 to 38 in that volume and the statement from Death is on page 27.

22 This is in the concluding passages of Kant's A Critique of Practical Reason. Among other translations readily available online, Thomas Kingsmill Abbott's translation of these passages is accessible at this link: http://www.philosophy-index.com/kant/critique-practical-reason/conclusion.php. Accessed 24/02/18.

23 This attribution is at the picture of Victor Ekpuk's painting Sunrise, an adaptation of the Nsibidi spiral, in the section on Nsibidi at the site of the Inscribing Meaning: Writing and Graphic Systems in African Art exhibition of the Smithsonian National Museum of African Art. https://africa.si.edu/exhibits/inscribing/nsibidi.html. Accessed 24/02/18. 
deathlessness, in relation to the complementary expression ìwà l'ewà, "character or inward being is beauty", is amplified by its correlation with the Afa idea of ultimate vision as consisting in the integrative awareness of materiality and its correlative spiritual being, as these issue from a cosmic matrix and Mazisi Kunene's account of Zulu epistemology in Anthem of the Decades (1981) depicting this unity in terms of the image of harmony of being projected by the circularity of a calabash, a visual corollary to the conjunction of the particular and the universal, the temporal and the eternal. Reinforcing the picture of the circularity of a calabash is the symbolism of the chameleon's eyes rotating in a three-hundred-and-sixty-degree motion as evocative of comprehensive perception of the possibilities of existence achieved through the conjunction of knowledge of the particulars of reality and the universal implications of those particulars in a synthesis that unifies all contraries, the living and the dead, the physical and the non-physical, matter and spirit, past and present, time and eternity, space and infinity, in a perceptual synthesis.

These are grand ideas, resonating with the loftiest conceptions of the human aspiration to reach a cognitive unity, different but correlative ideations ranging from the Platonic dialogues to the Hindu to the Western Enlightenment thinkers' emphasis on expansive forms of ratiocination. All possibilities of knowledge are integrated within the compass of the interpretation of Yorùbá theory of perception in terms of a continuum representing motion from sensory perception to critical thinking, intuition and witchcraft to deathlessness and its complementation by the Afa idea of unifying insight of the physical and spiritual worlds and the Zulu conception of the possibility of a compendious grasp of the unity of being.

Are these ideas admirable but questionable aspirations? Do they reflect what a scholar of the work of the Greek philosopher Aristotle described as the "ultimate impossibility of conceptually unifying all of being"? ${ }^{24}$ Do they point to the possibility of achieving an interpretive synthesis of the kind Stephen Hawking argues is a central goal of scientific cosmology, distilling the structure, dynamism and meaning of the cosmos in terms that enable people see "the mind of God" (Hawking 1988), an aspiration correlative with its more modest ancestor, Isaac Newton's expression, in Mathematical Principles of Natural Philosophy (1687), of relationships between cosmic being represented by the eternity and infinity of God and cosmic laws, exemplified by his discovery of the concept of universal gravitation and his derivation of the laws of motion, both terrestrial and planetary?

24 This comes from the writer of an Encyclopaedia Britannica article on Aristotle in an edition of the reference work the edition number of which I don't recall. 


\section{How Practical?}

The movement from ojú òde / ojú lásán / ose naabo to ojú inú / ojú okàn/ ose ora is a progression of forms of knowledge of which I expect that a significant number of people have had experience to varying degrees, as attested by the cognitive systems emerging at various points in various civilizations. Though not all the cognitive processes listed by Lawal are privileged at every point in different civilizations, they are all vital for the actualization of the totality of human cognitive potential. Everyone has experience of visual cognition, thinking, imagination, memory, critical analysis and intuition, though intuition is an ambiguous and often opaque cognitive category, even though vital at times. Everyone also has encounters with dreams, though their cognitive significance is controversial, as the illuminating labours of the pioneering psychologists Sigmund Freud, Carl Jung and their successors demonstrate.

What about trance as a suspension of conventional awareness in the context of entry into another reality? I expect people undergo this outside the religious contexts often associated with it but might not recognize the experience as trance, perhaps mistaking it instead for intense daydreaming, that being one means of entry into trance. What about prophecy? I expect people also experience this from time to time, in terms of an intuitive grasp of the future or of likely outcomes, without being able to trace precisely how this knowledge emerges, even if one may relate it, like some forms of intuition, to subliminal knowledge apprehended and fused at the level of the subconscious, as William Empson (1963) describes understanding in poetry. What about extra-sensory perception? I also expect people actualize this in various ways, such as being able to discern another person's feelings from touching them or listening to them, even when those feelings are not explicitly expressed. I think, however, that this category is less common than the others. What about witchcraft? That would depend on what Lawal means by witchcraft.

The study of àjé, which may be interpreted as witchcraft, is a significant subject in Yorùbá Studies, represented, among others, by Barry Hallen and J. O. Sodipo's pioneering Knowledge, Belief and Witchcraft (1997), Teresa Washington's Our Mothers, Our Powers, Our Texts: Manifestations of Aje in Africana Literature (2005) and The Architects of Existence: Aje in Yoruba Cosmology, Ontology, and Orature (2014). Pierre Verger's Ewe: The Uses of Plants in Yoruba Society describes a simple do-it-yourself ritual using plants and incantations, to initiate oneself into becoming àjé (1995). Àjé may be described as an autonomous spirituality centred in the development of unconventional human powers. Autonomous because it is based less on belief in deities or on the full scope of meaning developed by Yorùbá origin òrịà cosmology but simply focuses on the creative possibilities of the human being as it may 
be unleashed by the right factors. Central to these abilities is the belief in the power to move from one point to another without physical motion. This movement may involve entering into an otherwise invisible dimension associated with that location. This possibility is represented by accounts of witches meeting in trees or forests, environments that could demonstrate a form of energy that facilitates such extra-physical motion and congregation. This summation comes from my own experience as correlated with Southern Nigerian conceptions of witchcraft, particularly the Yorùbá àjé and the Benin azen. ${ }^{25}$

\section{Adapting Yorùbá Theory of Perception in Educational Theory and Practice}

Can all these ideas and insights, in their multilevels of complexity and abstractness be adapted to educational theory and practice? I believe so.

\section{Education as Training for Living}

Such a system could be centred, not so much in the development of particular points of knowing, the mastery of specific forms of knowledge, the various ways in which knowledge is developed, organized and applied, but in the cultivation of an attitude to life, in relation to which particular understanding and skills are developed. This focus on an attitude to life is grounded in the Yorùbá conception of the course of human life as dramatizing a conjunction between the aspects of the self, known as ori ode, the biological head and orí inú, the inward head, the centre of the self, the embodiment of the individual's ultimate potential, a potential grounded in the relationship between the self and ultimate reality represented by the creator of the cosmos. ${ }^{26}$ This account sums up in purely conceptual terms an understanding of the meaning of the combination of conceptual expression and mythic dramatization through which this idea is often articulated in its classical context.

Whatever one might think of the factuality of these bold summations on this mysterious topic of perennial fascination, the total scope of human nature

25 I describe this experience in "Encounters with the Unknown: Forest Initiations: A Meeting in No-Space". Facebook. https://www.facebook.com/notes/ oluwatoyin-vincent-adepoju/encounters-with-the-unknownforest-initiations-a-meeting-in-no-space/418787584102/. Accessed 18/02/2018. My earlier discussions of witchcraft, particularly in the Yorùbá context, can be found under "İyá mi Àjẹ" in "Linked List of Publications of Oluwatoyin Vincent Adepoju by Subject. In Progress". Facebook. https://www.facebook.com/notes/oluwatoyin-vincent-adepoju/linked-list-of-publications-of-oluwatoyin-vincent-adepoju-by-subject-in-progress/10154545039249103/.Accessed 18/02/2018.

26 Idowu (1962), among others, elaborates on the fundamental ideas and myths about orí. The distinction between the different aspects of orí is discussed by Abiodun (2008). 
and its relationship to the possibilities dramatized in the human being's life journey, these ideas present valuable possibilities that may be adapted for creative use.

\section{Questions Integrating the Philosophical and the Existential}

What are the proximate, the immediately obvious, the underlying yet not readily knowable, as well as the more distant factors that shape one's experiences and one's response to those experiences at a particular point in time and space? What is the nature of the dialogue between the various aspects of oneself as these emerge in particular circumstances within the stream of living from one day to the next and how may one best position oneself in relation to this dialogue? What possibilities of the self are at play in particular situations? Are there within oneself any creative compulsions or urges that suggest an orientation that may relate to values fundamental to the self, a sense of ultimate direction perhaps? How may one build a relationship between the various ways of achieving understanding, the sensory, the ratiocinative or intellectual, the emotional and the intuitive, in relation to reaching out to sources of knowledge and of power within and beyond the self and the material world in order to maximise the possibilities of various situations and of the stream dramatized by the flow of one's life?

These questions are an adaptation of the philosophy actualized in Ifa divination, a system developed in Yorùbá civilization as a means of mediating between the various aspects of the self. This divinatory system is described as a means of knowing the will of the orí, understood as the immortal essence of one's self which embodies one's ultimate possibilities, without whose consent no orisa or deity can bless one, the ever present companion who follows one on all journeys, even the most distant, the journey of death, invoked to bear testimony on behalf of the querent at each divination session, as this process is summed up by various sources. ${ }^{27}$ Adapting such ideas to a philosophical and educational framework outside its original context may involve distilling

27 This description of the role of orí in Ifá divination is adapted from Abimbola (1975, 1977a, 1977b), and from the verbal descriptions of Babaláwo Joseph Ohomina, an aspect of whose ideas on Ifá I discuss in "Cosmological Permutations: Joseph Ohomina's Ifa Philosophy and the Quest for the Unity of Being”. Facebook. https://www.facebook.com/ notes/oluwatoyin-vincent-adepoju/cosmological-permutations-joseph-ohominas-ifa-philosophy-and-the-quest-for-the-u/10153612717949103/. Accessed 18/02/2018. These ideas are reinforced and sharpened for me by the conjunctive description of quest for direction in strategic situations through the Spiritual Exercises of St. Ignatius of Loyola, the book he began at the time of discovering his Christian vocation, as this book is interpreted by the 20th century Catholic theologian, Karl Rahner in a version of the text edited by him (1965). The ideas are further enriched by my reading of the entry under "Spiritual Direction", a central practice in Catholic spirituality, in Rahner (1975). 
what one understands of the essential value of these ideas as they can be appreciated by most people as logically sound without having to give assent to the more controversial spiritual, supra-rational aspects of the constellation of ideas and practices that constitute the divinatory equation, while striving to maintain the aspiration to reach beyond the purely ratiocinative and immediately cognizable to cognitive possibilities conventionally beyond human reach, this transgressive aspiration being the rationale of divination.

In so distilling these ideas, one attempts a transposition of vision and method dramatized by my summations of questions one may ask oneself in conducting what may be seen as a self-navigated divinatory process in which one's capacity for reflection conducts the divinatory encounter. This self-enquiry thus becomes the analogue of the traditional divinatory procedure in which the diviner casts the divinatory instruments, the ọpè chain, or the ikin, the divination nuts, reading the oracle's response to the query from the symbolic patterns assumed by the fall of the instruments. In this transposition, the temporal progression and the situational context of one's life become the divinatory template, the symbolic equivalent of the opon Ifá, the cosmographic sculptural form on which Ifá divination may take place, the structure of the opon and the carvings that populate the form representing the convergence of various factors in enabling the divinatory procedure $^{28}$ in terms of what Velma Love (2019) describes as "Ifá Divination as Sacred Compass for Reading Self and World."

What is the significance of these ideas for a theory of perception? Their implication consists in the fact that a theory of perception may demonstrate an integration of epistemology and metaphysics, a perception of one's life as a whole, in the context of the cosmic processes within which that life unfolds. What is the ultimate point of gaining depth of understanding of discrete phenomena, even in terms of breadth of knowledge in particular disciplines, and not be able to reach such breadth of understanding in relation to the general act of living one's own life, the strategies through which it may be best navigated and the significance of its development?

Hence, the movement from ojú òde to ojú inú, from basic perception to entry into ontological depth, is ultimately grounded in a movement from ori ode, the biological identity represented by the human head to orí inú, the immaterial essence of self that integrates ultimate potential in relation to ultimate being. The orí ode / orí inú matrix may thus be understood as superordinate categories of human being and becoming, the framework within

28 Abimbola's books listed earlier are very good on the general structure of the divinatory process while Pemberton et al (1989) is excellent in providing a fundamental description of the role of the opọ́n ifá in divination. 
all which all other penetrative progressions, all motion from ojú òde to ojú inú take place, a breadth of understanding that is a central goal of education as a means of facilitating the cultivation of human potential in relation to the entire stream of living and its expression in engagements with particular bodies of knowledge and the demonstration of skill in use of distinctive forms of knowing. ${ }^{29}$

\section{From the General to the Particular}

Having given an overview of how Yorùbá philosophy of perception relates to cultivating insights on the course of human experience as a whole, how may this theory be applied to the study of particular phenomena and disciplines and how is such study particularly relevant in the Nigerian context?

Knowledge is best reached through a combination of assimilation, reflection and action. Within this context, appreciation of the fact that understanding operates in terms of degrees of penetration facilitates moving from its surface to its depths. The surface of a phenomenon, its point of immediate access, a physical or metaphorical location, is known in Yorùbá as ojú, the "face" of that phenomenon. This understanding is exemplified by the description of the visual inscriptions representing the odu Ifá, the organisational categories of Ifá, as ojú odù ifá, the "face of odù Ifá" (Abimbola 1977), a point of immediate entry into a vast network of literary forms and their myriad symbolic values correlative with a range of potentially unknown scope of human experiences, a hermeneutic complex that gives an idea of the range of interpretive possibilities that may emerge from consideration of the surface, the face, the most immediately accessible aspect of a phenomenon, as one penetrates deeper, through reflection, imaginative identification, intuitive apprehension, evocations of memory, critical analysis, and other relevant cognitive strategies, to its profounder levels of significance. Thus, like the Greek philosopher Aristotle, in the Metaphysics, one may move from sense perception to exploration of the form, progression and significance of phenomena and their relationship with other phenomena, insights unfolding into a grasp of the meaning of these phenomena in the context of the underlying structures of existence. ${ }^{30}$

29 This formulation of forms of knowledge benefits from Hirst's conceptions (1972 and 1975).

30 The compactness and the modern translation style of The Works of Aristotle, Vols.1 and 2: Great Books of the Western World, Vols. 8 and 9. Encyclopaedia Britannica, 1952, trans. by W.D. Ross et al, has provided my own contact with Aristotle. Of course, many more recent translations exist. I find Lear (1988) a magnificent introduction to the total scope of the Greek thinker's cognitive enterprise. 
An appreciation of knowing as a developmental process, of knowledge as a dynamic acquisition demonstrating a range of apprehensive possibilities, as suggested by Lawal's depiction of Yorùbá theory of perception, could contribute to galvanizing learners to work at engaging the act of learning as dynamic rather than passive, to be active enablers, active workers in the act of building knowledge, understanding knowledge as more of a collaboration between the self and information than something simply assimilated from without, as something that the learner contributes to by bringing their unique mental framework to the subject, an idea amplified by the Yorùbá understanding of all conscious forms of being as demonstrating a distinctive creative capacity deriving from "àsẹe", a cosmic force that enables being and becoming. ${ }^{31}$ This understanding of individuality of creative enablement central to the being of the individual suggests questions of the individuality of response to situations, to learning and to the entire enterprise of living, within the framework of the commonalities that define human existence.

What are the ways through which a particular person learns best? What best motivates a specific student? Beyond these immediate questions, what is the role of the learning experience in the person's understanding of their life trajectory? Is it possible at some point in time to build a depth of motivation arising from the integration of the educational experience in a sense of vocation, an orientation of one's "life and work in terms of an ultimate sense of mission", as Webster's Dictionary describes the concept of vocation? Most educational systems represent a tension between autonomy and restriction, between the learner's discovery of cognitive universes through their own distinctive methods of exploration and the shaping of learning processes and outcomes by a set of prescriptions handed down by the creators of the educational system. "Formal education like religion, thrives on standardisation and in my view it is anti-human nature", states Precious Imuwahen Ajoonu in a Facebook discussion initiated by Temi Dayo's post on kindergarten and primary school education in Nigeria. ${ }^{32}$ She suggests that the challenges of the Nigerian educational system are best understood within the framework of the challenges of educational systems globally:

On the schooling system we have a global crisis. In 20 years or less Artificial Intelligence would be our core competitors. [The] Question is [is] humanity prepared for this quantum change?

31 A good introduction to àse is provided by Drewal et al (1989).

32 Comment in a Facebook discussion initiated by Temi Dayo's post of 18/02/2018. Link to Dayo's post: https://www.facebook.com/temi.ahanmisi/posts/1840763089331298 
I follow the works of Ken Robinson ${ }^{33}$ who argues that education kills creativity ${ }^{34}$. He is right and no he is not Nigerian. We would have to personally determine how we choose to educate our children. I think we have passed the era of standardisation.

Create a new hybrid curriculum and it would still not capture every single human being.

She relates these concerns to the evolving world of work:

These conversations need to happen. We can overhaul our curriculum to include more practical life based learning.

The jobs of the future are unknown. Educating children using the industrial age curriculum is a recipe for disaster. We would need to find our own way. Home schooling, a mixture of both and so on, all geared towards developing critical thinking abilities.

She correlates these ideas with her own cognitive history, incidentally striking a note, that resonates with Lawal, on the capacities represented by ojú $i n u$, specifically, the non-linear, non-prescriptive and individualistic creativity demonstrated by critical analysis, imagination, intuition, empathy and benevolence:

My career today is far from what I thought it would be in the 90s. It is the ability to think critically and adapt to ever changing technologies that have helped me survive. It is our elastic minds that would place us above Artificial Intelligence. It is empathy, creativity, service to others that would put us way ahead of our machines.

33 Most likely a reference to Sir Ken Robinson described on his website sirkenrobinson.com/( accessed 01/03/18) as "TED speaker, education and creativity expert" and on his Wikipedia page https://en.wikipedia.org/wiki/Ken_Robinson (educationalist) ( accessed 01/03/18) as "British author, speaker and international advisor on education in the arts to government, non-profits, education and arts bodies".

34 I expect he makes this case in his TED talk, "Do Schools Kill Creativity?" (https:// www.ted.com/talks/ken_robinson says schools kill creativity) (accessed 01/03/18) most likely among other presentations of his, as evident from the various video options of his talks on the YouTube page of the TED talk linked here. Joe Kirby's "What Sir Ken Got Wrong" https://pragmaticreform.wordpress.com/2013/10/12/what-sir-ken-got-wrong/ (accessed 01/03/18) in his Pragmatic Education blog critiques Robinson's views on education in a discussion to which Kirby's readers contribute. 
She then addresses intergenerational influences in relation to these issues:

Finally, I agree we need to do something urgently. I would strongly encourage parents to look inwards. Are you an evolving being or set in your ways? Fix that then we move to the children. Least we create another ineffective pill for the same sickness.

My point is, we need to be that which we seek. We cannot close our minds to learning and expect kids to automatically be critical thinkers, it won't happen.

Minola Momodu, in the same discussion, sums up and amplifies similar ideas, incidentally telescoping the vision of this essay with succinct force: "...to learn is to think, challenge and be open to alternative approaches and schools of thought".

In discussing with a couple of secondary school students who have experienced both the Nigerian and English educational systems, the one quality they both mentioned as absent from their experience with the Nigerian system particularly as compared with the English, was the lack of emphasis on creative learning. The focus of the Nigerian educational system they experienced was on being able to memorize what had been taught in class and to repeat it in examinations, the kind of education Paulo Freire described as "banking education" (Freire 1970) in which knowledge is held like money in a bank and returned to the depositor through the medium of an examination, and if I might add, recalling my experience teaching and learning in a Nigerian university more than a decade ago, some students being able to give the money back with interest, in this instance, in the form of new knowledge which they have added to what was earlier taught or new approaches to the knowledge earlier passed on to them. Another person I spoke to stated that Nigerian education is too often marred by cheating in examinations, a culture arising from a vision of education as a necessary evil, an unavoidable hurdle to positioning oneself to get on in society through a job rather than as a means of enriching the mind. Within such a context, therefore, the fact of possessing a certificate attesting to one having passed through an educational system is more important to many than the creative reformation of the mind enabled by diligent engagement with the task of learning.

Education in Nigeria may thus be assessed in terms of its place on a continuum of cultivation of creativity, with totally prescriptive learning at the lowest end of the scale and totally autonomous learning at the highest end. Totally autonomous learning is close to the example of Abraham Flexner (1866-1959), an advocate of "creativity, individual expression, exploration, and pragmatic learning" (Thelin 2004, 362), whose Abraham Flexner's School, according to 
the Wikipedia essay on the institution, "did not give out traditional grades, used no standard curriculum, refused to impose examinations on students, and kept no academic record of students. Instead, it promoted small learning groups, individual development, and a more hands-on approach to education." Yet, "graduates of his school were soon accepted at leading colleges", Flexner later summing up his perspectives on education in The American College: A Criticism (1908). ${ }^{35}$

Close to that model of perhaps relatively absolute freedom within an educational organization is the Peter Thiel fellowship which provides for students to take a break from or opt out of schooling to pursue entrepreneurial projects of their own design within the context of the financial and infrastructural support provided by the fellowship. ${ }^{36}$ Proximate to these examples is the US university undergraduate elective system, in which students choose the courses they study, introduced by "Thomas Jefferson [in] founding the University of Virginia [encouraged by] other reformers during the 1840s," ${ }^{37}$ and consolidated by Charles Williams Eliot as Harvard President, in which students followed no set courses but ranged freely across any disciplines of their choice. ${ }^{38}$ The Wikipedia article on Eliot sums up his philosophy in a manner relevant for the educational direction developed in this essay:

Under Eliot's leadership, Harvard adopted an "elective system" which vastly expanded the range of courses offered and permitted undergraduates unrestricted choice in selecting their courses of study - with a view

35 “Abraham Flexner”, Wikipedia. https://en.wikipedia.org/wiki/Abraham Flexner. Accessed 24/02/2018. And also presented in Parker (1962) and Seyal (2013).

36 The Thiel Fellowship describes its vision this way on its website: "The Thiel Fellowship gives $\$ 100,000$ to young people who want to build new things instead of sitting in a classroom. A different path for everyone. College can be good for learning about what's been done before, but it can also discourage you from doing something new. Each of our fellows charts a unique course; together they have proven that young people can succeed by thinking for themselves instead of competing on old career tracks. Pursue ideas that matter instead of mandatory tests. Take on big risks instead of big debt". http://thielfellowship.org/. Accessed 24/02/18.

37 "Charles Eliot (1834-1926) - Harvard: From College to University, Recruiting a Superior Faculty, The Elective System”, StateUniversity.com. http://education.stateuniversity.com/pages/1951/Eliot-Charles-1834-1926.html . Accessed 24/02/18

38 The Harvard page on Eliot seems to quote him in describing this system as a "spontaneous diversity of choice" [ which] in turn, stimulated an open-ended curriculum". Thomas J. Denham's “The Elective System or Prescribed Curriculum: The Controversy in American Higher Education", at https://files.eric.ed.gov/fulltext/ED471740.pdf, surveys the history of this system in US higher education, and Crow and Dabars (2015) presents the views of its critics in the context of the history of US higher education. 
to enabling them to discover their "natural bents" and pursue them into specialized studies.

Echoing Emerson, he believed that every individual mind had "its own peculiar constitution". The problem, both in terms of fully developing an individual's capacities and in maximizing his social utility, was to present him with a course of study sufficiently representative so as "to reveal to him, or at least to his teachers and parents, his capacities and tastes." An informed choice once made, the individual might pursue whatever specialized branch of knowledge he found congenial. ${ }^{39}$

\section{Education and the Meaning of Life}

Why are we here on earth at all as human beings? What is the rationale of our existence? What is the ultimate significance of our actions against the background of these supervening questions? How best may these queries be explored? These enquiries may be seen as the most fundamental of human questions, addressing the very foundations of human existence, bedrock platforms in relation to which all human activity has meaning.

Beyond much of education as currently understood, regardless of the degree to which particular systems facilitate the cultivation of creativity, is the question of the relationship of education to the ultimate needs of a person, a need that, in harmony with Viktor Frankl's Man's Search for Meaning (1959), may be seen as a hunger for meaning, a sense of justification of existence, and the most far reaching of this sensitivity to fundamental value being an orientation towards ultimate significance, a correlation of one's individuality with the cosmic immensity of which one is a part. Can education in Nigeria not also be assessed in relation to the degree to which it facilitates the fulfilment of this central drive, a drive that gives value to every human activity, a value that stretches from the need to survive by keeping oneself alive, to expanding one's interactive space through socialization and family making and the creation of various forms of impact beyond oneself to the sense of a connection to something that validates one's existence, however that something is construed? The strategy of the current globally dominant educational system which originated in Enlightenment Europe has been to leave such questions for philosophers and religious people while training people in a mix of educational programs centred in general education of the mind, one way of

39 "Charles William Eliot". Wikipedia. https://en.wikipedia.org/wiki/Charles_William Eliot. Accessed 24/02/18. 
characterizing a liberal education, and more directly focused skills oriented learning, centred on the accomplishment of specific tasks, one way of describing a professional education. Can Yorùbá epistemology contribute to the effort to unify these three aspects of education, the metaphysical, the liberal and the professional?

\section{Education and Ethical Commitment}

How may one encourage people to commit themselves to an abstraction, such as the values represented by iwà l'ewà, an understanding of the essence of value as an inward beauty? How could they be brought to focus themselves in a quest for abstract immortality in a non-dogmatic, non-sectarian and non-doctrinal context, to transcendence of the mutability of existence through a consummation of this aesthetic orientation, as suggested by àikú pari iwà? The methods through which those goals may be pursued would represent the specific modalities of an educational system inspired by these incandescent values from Yorùbá philosophy, values that take the mind beyond the culture of corruption that has become so tragically glaring in Nigeria, in a context where crude satisfactions are the norm, in which there is little thought for inner wealth.

\section{Education and the Transformation of Reality}

Related to those more immediately moral issues is education as training in how to transform reality, as creativity may be perceived. Various methods exist for pursuing creative learning. The contribution of Yorùbá philosophy to theory and technique in this field would include an emphasis on individual agency, on self-directed discovery, most likely within environments that facilitate such individually generated progression, in the spirit of Chinua Achebe's quotation of the Igbo expression "ike di na awacha na awacha" ("power flows in many channels"), in his exposition of the Igbo concept of $i k e$, "energy", a variant of the body of ideas to which the Yorùbá concept of "àse" belongs, a conglomeration of thought also evoked by another Achebe quote from Igbo thought, "Everyone and his own", suggesting the pervasive enablement of creativity as fundamental of human being, its expression unique to each person (Achebe 1997).

This essay has described, in general terms, an understanding of the implications for educational theory and practice of classical Yorùbá theory of perception as concisely yet comprehensively summed up by Babatunde Lawal in "Àwòrán", in conjunction with Rowland Abiodun's discussion of relationships between Yorùbá epistemology and ethics in Yoruba Art and Language, as these ideas are complemented by John Umeh's description of Igo Afa 
epistemology in After God is Dibia, and as these conjunctions are reinforced by their resonance with Mazisi Kunene's account of Zulu theory of perception in Anthem of the Decades, bringing these ideations into dialogue with other bodies of knowledge.

\section{Works Cited}

Abimbola, Wande (1975), Sixteen Great Poems of Ifa (Niamey: UNESCO) Abimbola, Wande Abimbola (1977), Ifa Divination Poetry (New York: Nok). Abimbola, Wande (1977), Ifa: An Exposition of Ifa Literary Corpus (Ibadan: Oxford University Press)

Abiodun, Rowland (2008), "Who was the First to Speak: Insights from Ifa Literature and Sculptural Repertoire" in Jacob Olupona and Terry Rey (eds.) Orişà Devotion as World Religion: The Globalization of Yorùbá Religious Culture (Madison: University of Wisconsin Press), 51-69.

Abiodun, Rowland (2014), Yoruba Art and Language: Seeking the African in African Art (New York: Cambridge University Press).

Achebe, Chinua (1997), "The Igbo World and Its Art," in Emmanuel Chukwudi Eze (ed.) African Philosophy: An Anthology (Oxford: Wiley-Blackwell), 435-437.

Adebisi, Ademakinwa (2015), "Yoruba Traditional Education Philosophy in the Evolution of a 'Total Man'," International Journal of Humanities and Cultural Studies Vol. 2, No. 2: 33-45.

Akinsola, Esther (2011), "Omoluwabi’s Approach to Educating the African Child," in A. Bame Nsamenang and Thérèse Mungah Tchombé (eds.) Handbook of African Educational Theories and Practices: A Generative Teacher Education Curriculum (Bamenda: Human Development Resource Centre), 221-232.

Akinwale, Ayanleke (2013), "Yoruba Traditional Education System: A Veritable Tool for Salvaging the Crisis Laden Education System in Nigeria," Academic Journal of Interdisciplinary Studies Vol. 2, No. 6: 141-145.

Aladejana, Tony Idowu (1979), An Axiological Analysis of Yoruba Education. PhD Diss. Chicago: Loyola University.

Backman, Jussi (2015), "Towards a Genealogy of the Metaphysics of Sight: Seeing, Hearing, and Thinking in Heraclitus and Parmenides," in Antonio Cimino and Pavlos Kontos (eds.) Phenomenology and the Metaphysics of Sight (Leiden: Brill), 11-34.

Crow, Michael and Dabar, William (2015), Designing the New American University (Baltimore: John Hopkins University Press).

Drewal, Henry J. (2016), "Ifa: Visual and Sensorial Aspects," in Jacob Kehinde Olupona and Rowland Abiodun (eds.) Ifá Divination, Knowledge, 
Power, and Performance (Bloomington and Indianapolis: Indiana University Press), 325-339.

Drewal, Henry J. (2005), "Senses in Understandings of Art," African Arts 38(2):1-96.

Drewal, Henry J. (2009), "Material, Sensorial Religion: The Case of Mami Wata," Material Religion: The Journal of Objects, Art and Belief 5(2):226-229. Drewal, Henry John, Pemberton, John and Abiodun, Rowland (1989), Yoruba: Nine Centuries of African Art and Thought (New York: Harry N. Abrams) Empson, William (1963), Seven Types of Ambiguity: A Study of Its Effects on English Verse (London: Chatto and Windus).

Falola, Toyin (ed. 2013), Esu: Yoruba God, Power, and the Imaginative Frontiers (Durham: Carolina Academic Press).

Fatunmbi, Awo Fa'lokun (2000), Esu-Elegba: Ifa and the Divine Messenger (New York: Original Publications).

Fayemi, Ademola Kazeem (2009), "A Philosophical Examination of the Traditional Yoruba Notion of Education and its Relevance to the Contemporary African Quest for Development," Thought and Practice Vol.1, No. 2. (Dec.): 41-59.

Frankl, Viktor (1959), Man's Search for Meaning: An Introduction to Logotherapy (London: Faber and Faber).

Freire, Paulo (1970), Pedagogy of the Oppressed, trans. by Myra Ramos (New York: Herder and Herder).

Gates Jr., Henry Louis (1988), The Signifying Monkey: A Theory of African-American Literary Criticism (Oxford: Oxford University Press).

Gyekye, Kwame (1995), An Essay on African Philosophical Thought: The Akan Conceptual Scheme (Cambridge: Cambridge University Press).

Hallen, Barry and Olubi Sodipo, John (1994), “The House of the 'Inu': Keys to the Structure of a Yoruba Theory of the 'Self'," Quest: Philosophical Discussions 8, no. 1: 3-23.

Hallen, Barry and Sodipo, John Olubi (1997), Knowledge, Belief and Witchcraft: Analytic Experiments in African Philosophy (Stanford: Stanford University Press).

Hallen, Barry (2000), The Good, the Bad, and the Beautiful: Discourse about Values in Yoruba Culture (Bloomington and Indianapolis: Indiana University Press).

Hawking, Stephen (1988), A Brief History of Time: From the Big Bang to Black Holes (New York: Bantam).

Hirst, Paul (1972), "Liberal Education and the Nature of Knowledge" in Reginald Archambault's (ed.) Philosophical Analysis and Education (London: Routledge and Kegan Paul), 113-138 
Hirst, Paul (1975), Knowledge and the Curriculum: A Collection of Philosophical Papers (London: Routledge and Kegan Paul).

Hyland, Ranjana Thapalyal (2016), Education as Mutual Translation: A Yoruba and Vedantic Interface for Art School Pedagogy. PhD Diss. London: Goldsmiths, University of London.

Idowu, Bolaji (1962), Olodumare, God in Yoruba Belief (London: Longmans). James, William (1902), The Varieties of Religious Experience: A Study in Human Nature (London: Longmans, Green, \& Co.).

Jonas, Hans (1954), “The Nobility of Sight," Philosophy and Phenomenological Research Vol. 14, No. 4 (June): 507-519.

Jonas, Hans (1962), "Homo Pictor and the Differentia of Man," Social Research Vol. 29, No. 2 (Summer): 201-220.

Katz, Steven T. (2013), Comparative Mysticism: An Anthology of Original Sources (Oxford: Oxford University Press).

Kunene, Mazisi (1981), Anthem of the Decades (London: Heinemann).

Lakoff, George and Johnson, Mark (1999), Philosophy in The Flesh: the Embodied Mind and its Challenge to Western Thought (New York: Basic Books).

Lawal, Babatunde (2008), "Ejiwapo: The Dialectics of Twoness in Yorùbá Art and Culture," African Arts 41, no. 1: 24-39.

Lawal, Babatunde (2001), "Àwòrán: Representing the Self and its Metaphysical Other in Yoruba Art," The Art Bulletin Vol. 83, No. 3 (Sep.): 498-526.

Lear, Jonathan (1988), Aristotle: The Desire to Understand (Cambridge: Cambridge University Press).

Love, Velma (2016), "Ifá Divination as Sacred Compass for Reading Self and World," in Jacob Olupona and Rowland Abiodun (eds.) Ifá Divination, Knowledge, Power, and Performance (Bloomington and Indianapolis: Indiana University Press), 181-192.

Okediji, Moyo (2010), "Museums, Modernity and Mythology: A Semioptic Review," RES 52, Fall: 73-84.

Okediji, Moyo (2010), "Semioptics of Africana Arts," in Tejumola Olaniyan and James Sweet (eds.) The African Diaspora and the Disciplines (Bloomington and Indianapolis: Indiana University Press), 382-416.

Okediji, Moyo (2010), "Semioptics of Falolaism: Visual fractures Beyond Ethnic Boundaries," in Niyi Afolabi (ed.) Toyin Falola: The Man. The Mask, The Muse (Durham: Carolina Academic Press), 263-280.

Okediji, Moyo (2015), "African Art and Language as Semioptic Text," The Art Bulletin, 97:2, 123-139.

Parker, Franklin (1962), “Abraham Flexner, 1866-1959”, History of Education Quarterly Vol. 2, No. 4 (Dec.): 199-209.

Rahner, Karl (1965), Spiritual Exercises (New York: Herder and Herder). 
Rahner, Karl (1975), Encyclopaedia of Theology: A Concise Sacramentum Mundi (London, Burns \& Oates).

Reps, Paul (1957), Zen Flesh, Zen Bones (Clarendon: Tuttle).

Seyal, M. Saleem (2013), "Abraham Flexner: His Life and Legacy," Hektoen International Journal: A Journal of Medical Humanities Vol. 5, Issue 3 (Summer): http://hekint.org/2017/01/29/abraham-flexner-his-life-and-legacy/. Accessed 24/02/18

Thelin, John R. (2004), "Review of Thomas Neville Bonner's Iconoclast: Abraham Flexner and a Life in Learning," The Journal of Higher Education Vol. 75, No. 3 (May - June): 362-363.

The Ten Principal Upanishads (1937), trans. by W. B. Yeats and Shree Purohit Swami (London: Faber and Faber).

Umeh, John (1999), After God is Dibia: Igbo Cosmology, Divination and Sacred Science in Nigeria (London: Karnak House).

Varela, Francisco, Rosch, Eleanor and Thompson, Evan (1991), The Embodied Mind: Cognitive Science and Human Experience (Cambridge, MA: The MIT Press).

Verger, Pierre (1995), Ewe: The Uses of Plants in Yoruba Society (Rio de Janeiro: Oderbrecht).

Waghid, Yusef (2014), African Philosophy of Education Reconsidered: On Being Human (London: Routledge).

Washington, Teresa (2005), Our Mothers, Our Powers, Our Texts: Manifestations of Aje in Africana Literature (Bloomington and Indianapolis: Indiana University Press).

Washington, Teresa (2014), The Architects of Existence: Aje in Yoruba Cosmology, Ontology, and Orature (Oya's Tornado). 